Tyndale Bulletin 65.2 (2014) 305-308

\title{
CANONICAL INTERPRETATIONS OF THE SONG OF SONGS ${ }^{1}$
}

\author{
Rosalind S. Clarke \\ (ros@theoldshed.me)
}

Traditional interpretations of the Song have recognised many allusions to the wider canon, which have been used as the basis for various kinds of allegorical readings. With the rise of alternative interpretations and a recent shift in focus towards methodological issues and ideological approaches to the Song, these canonical allusions have frequently been overlooked. Without advocating a return to allegorical interpretation, this thesis develops a canonical approach to the book, giving due attention to its literary, theological and ecclesiological nature. The Song proves to be a valuable test case for canonical interpretation since it is found in three distinct canonical contexts in the Hebrew Bible, the Greek Septuagint, and modern Christian Bibles.

The method of canonical interpretation developed in the first chapter takes as its starting point the nature of the canon as a historical, literary, ecclesiological and theological entity. Following the approach of Brevard Childs, it is assumed that the canonical meaning resides in the final form of the canon. Thus the internal shaping of canonical texts, and the placement of texts within the canon are both significant for interpretation. As a literary entity, the canon provides a network of intertexts for each book. Intertextual analysis thus forms the starting point for canonical interpretation. Several strategies of containment are required to identify the most significant canonical intertexts in each context: proximity, theme, and denotative sign. However, canonical interpretation is not limited to literary analysis since it must also reckon with the canon's self-presentation as divine discourse. The principles and categories of speech-act theory are used to interpret the text's discourse functions and effects.

1 Rosalind S. Clarke, 'Canonical Interpretations of the Song of Songs' (Ph.D. thesis, Aberdeen [Highland Theological College], 2014). Supervisor: Dr Jamie Grant. 
The substance of the thesis therefore consists of the application of this method of canonical interpretation to the Song of Songs. This is repeated for each distinct canonical context: the Wisdom literature, the Writings, and the wider Christian canon. In each, the strategies of containment are identified, with particular narrowing of thematic focus. A general intertextual reading is offered, showing the ways in which the intertexts collude or collide with the Song. Detailed analysis of certain passages with especially strong thematic or lexical links is also provided. In the final chapter, an internal speech-act hierarchy of the book is outlined and the canonical speech acts are identified.

For both the Wisdom Literature and the Writings, the intertextual analysis focuses on the identity of the Song's central male and female characters. Intertextual links are identified between the woman in the Song and Woman Wisdom, Female Folly, the faithful wife, and the adulteress. Detailed analysis is undertaken of: Sirach 24:13-31 with Song 4:8-5:1; Proverbs 7:1-27 with Song 2:8-3:5; and Proverbs 5:1519 with Song 4:1-5:1. The woman in the Song is shown to function as a test of wisdom for the reader, as a wisdom instructor for women, and as a means of collapsing the female dichotomy based on sexual activity. The man in the Song is a bridegroom who both embodies the Solomonic ideal and is better than the Solomonic reality. As king, he is presented as an exemplary figure, with particular insight into his exemplary private life. Insofar as the woman in the Song embodies Woman Wisdom, her husband embodies the ideal wisdom seeker.

While it is recognised that there is no discernible editorial intent behind the collection of the Writings, nonetheless it is argued that this group of texts forms a de facto literary context for the Song. Intertextual links are identified between the woman in the Song and various royal women and foreign women in the Writings. She is shown to be a beloved and exemplary wife by virtue of her royal connections. Together with Ruth and the anonymous bride of Psalm 45, the woman in the Song provides a counter-narrative to the silencing and oppression of foreign women in the Writings. The male figure in the Song is shown to be an idealised Yahweh-worshipper, identified with Solomon, the temple-builder. Like Boaz, he is a bridegoom-redeemer. Detailed intertextual analysis was undertaken between Psalm 45 and the Song.

The intertextual reading of the Song within the Christian Bible requires different and more stringent strategies of containment. The 
thematic focus is on marriage and this, together with the criterion of proximity, suggests that the prophetic books of Isaiah, Jeremiah, Hosea, and Ezekiel are significant intertexts. Detailed intertextual analysis of the Songs of the Vineyard in Isaiah 5 and 27, as well as the prophecies of restoration in Isaiah 35, Isaiah 62, and Hosea 14 generates the following complex of metaphors:

LOVER is VINEYARD OWNER is YAHWEH;

BRIDEGROOM is YAHWEH;

BELOVED is VINEYARD is ISRAEL;

BRIDE is LAND (ISRAEL) is PEOPLE (ISRAEL);

REVIVED LAND is RESTORED ISRAEL.

The Song of Songs is shown to participate in this complex of metaphors in the following ways:

BELOVED is VINEYARD;
BRIDE is LAND (ISRAEL);
BRIDE is REVIVED LAND.

It is argued that the marriage in the Song, when read in the intertextual context of the prophetic literature is a metaphor for the marriage between Yahweh and Israel.

Two further intertexts were added in this section, on the basis of their strong thematic and lexical links to the Song as well as their prominent status in the canon: Genesis 1-3 and Revelation 19-22. Following Phyllis Trible, it was shown that the Song is a depiction of redemption from the curses of Genesis 3. Reading the Song with Revelation 19-22 shows its implicit eschatological hope.

The speech-act analysis of these results shows that the different canonical contexts give rise to distinct, though related, speech acts. When read in the context of the Wisdom literature, the Song tests the wisdom of the reader, it evokes desire for greater wisdom, and it warns against unwise love. In the context of the Writings, the Song evokes desire for a spouse, and it exposes and counters female oppression. In the context of the prophetic books and the wider Christian canon, the Song expresses God's love to his beloved people, it evokes desire for God, and it stirs up an eschatological hope for the final consummation of that love and desire. The desire which the Song evokes in readers is variously directed towards woman wisdom, an ideal bride or groom, 
and towards Christ. These speech acts find their canonical coherence in the person of Christ, who is the wisdom of God and the bridegroom of the church.

The canonical method of interpretation developed in the thesis is shown to be effective in analysing the implications of canonical context for meaning and function. It has particular value for texts such as the Song which have multiple canonical contexts, but it can be effectively applied to any canonical text. Poetic and allusive texts such as the Song are more likely to sustain multiple canonical meanings and speech acts, but all canonical texts will have both meaning and function, which will be affected by their canonical context and status.

With respect to the interpretation of the Song itself, it is shown to be deeply embedded in the canon by means of many thematic and lexical connections, and its canonical status is a non-trivial factor in its interpretation. Since the Song exists only as part of the canon, it is argued that the canonical meaning of the book is integral to the text. This canonical meaning is inherently theological because of the canon's self-presentation as divine discourse. The Song speaks about divine wisdom, gives divine instruction concerning marriage, and demonstrates divine love. From this canonical perspective, the Song of Songs is indeed the Holy of Holies: the most intimate expression of God's love for his people which most powerfully evokes love as a response from the reader. 